\title{
Yield response of wheat to nitrogen and potassium fertilization
}

\author{
Muhammad Adnan ${ }^{1 *}$, Zahir Shah ${ }^{2}$, Hidayat Ullah ${ }^{1}$, Bushra khan $^{3}$, \\ Muhammd Arshad ${ }^{4}$, Ishaq Ahmad Mian², Gohar Ali khan², Mukhtar \\ Alam ${ }^{1}$, Abdul Basir ${ }^{1}$, Inayat-Ur- Rahman ${ }^{1}$, Murad Ali ${ }^{2}$ and Wasif Ullah \\ khan $^{5}$
}

1. Department of Agriculture, the University of Swabi, Pakistan

2. Department of Soil and Environmental Sciences, the University of Agriculture, Peshawar, Pakistan

3. Department of Environmental Sciences, University of Peshawar, Pakistan

4. Mountain Agriculture, Research Center (MARC) Gilgit Baltistan, Pakistan

5. Department of Plant Breeding and Genetics, University of Agriculture, Peshawar, Pakistan

*Corresponding author's email: madnanses@gmail.com

Citation

Muhammad Adnan, Zahir Shah, Hidayat Ullah, Bushra khan, Muhammd Arshad, Ishaq Ahmad Mian, Gohar Ali

khan, Mukhtar Alam, Abdul Basir, Inayat-Ur- Rahman, Murad Ali and Wasif Ullah khan. Yield response of wheat to nitrogen and potassium fertilization. Pure and Applied Biology. Vol. 5, Issue 4, pp868-875. http://dx.doi.org/10.19045/bspab.2016.50109

Received: 23/04/2016 Revised: 01/08/2016

Accepted: $12 / 08 / 2016$

Online First: 17/08/2016

\section{Abstract}

A field study was carried out to evaluate the impact of various nitrogen $(\mathrm{N})$ and potassium $(\mathrm{K})$ combinations on yield of wheat crop during winter 2012-2013. Two factorial randomized complete block design (RCBD) was used for the experiment. There were three levels of nitrogen $\left(90,120,150 \mathrm{~kg} \mathrm{~N} \mathrm{ha}^{-1}\right)$ and five levels of potassium $\left(0,30,60,90,120 \mathrm{~kg} \mathrm{~K}_{2} \mathrm{O} \mathrm{ha}{ }^{-1}\right)$. Nitrogen used at the rate of $150 \mathrm{~kg} \mathrm{ha}^{-1}$ significantly improved plant height, grains spike ${ }^{-1}, 1000$ grain weight, biological and grain yields of wheat. Similarly, $\mathrm{K}$ application at $90 \mathrm{~kg} \mathrm{~K}_{2} \mathrm{O} \mathrm{ha}{ }^{-1}$ significantly enhanced plant height by $8 \%$, grain spike ${ }^{-1}$ by $11 \%$, thousand grain weight by $18 \%$, biological yield by $42 \%$ and grain yield by $27 \%$ over control however, further increase in K level to $120 \mathrm{~kg} \mathrm{~K}_{2} \mathrm{O}$ ha $^{-1}$ did not significantly improve these parameters. It was concluded that $\mathrm{N}$ application at the rate of $150 \mathrm{~kg} \mathrm{ha}^{-1}$ in combination with $90 \mathrm{~kg} \mathrm{~K}_{2} \mathrm{O} \mathrm{ha}{ }^{-1}$ were optimum for achieving higher yield of wheat.

Keywords: Wheat; Nitrogen; Potassium; Yield; Fertilization

\section{Introduction}

Wheat (Triticum aestivum L.) is one of the most important food grain crop grown worldwide. It ranks first in the world cereal crops accounting for $30 \%$ of all cereal food worldwide and is a staple food for over 10 billion people in as many as 43 countries of the world. It provides about $20 \%$ of the total food calories for the human race [1]. Farming systems have improved over the years by increasing crop yields through the use of improved verities and increased fertilizer inputs. Several authors claim that at least 30 to $50 \%$ of yield growth is attributable to commercial fertilizers [2]. However, fertilizer inputs are increased due to increasing world inhabitants and the growth of agriculture into less fruitful areas. It also enlarged fertilizers cost and reduced fertilizer effectiveness. Such as the 
efficiency of nitrogen in grains production (maize, barley, wheat, rice, sorghum, millet, oats and rye) is about $33 \%$, with $67 \%$ losses producing a 15.9 billion US\$ annual losses [3].

Nitrogen $(\mathrm{N})$ occupies a conspicuous place in plant metabolism. All vital processes in plant are associated with protein of which nitrogen is an essential constituent. Consequently to get more crop production in nitrogen deficient soils its application is essential [4]. Similarly, potassium $(\mathrm{K})$ is the third important macro nutrient after nitrogen (N) and phosphorus (P) required by crop because it has an important osmotic role in plants efficiency, enzyme activation, carbohydrate and proteins syntheses [5] energy relations and assimilates translocation [6]. Shorter internodes, weaker straw, increased lodging and slower growth are the resulted symptoms of K deficiency.

$\mathrm{N}$ and $\mathrm{P}$ fertilization have played a major role in increasing wheat yield. However, wheat production sometimes is limited because farmers give little attention to $\mathrm{K}$ application. Due to the limited potash resources in Pakistan and increasing fertilizer cost, efficient application of $\mathrm{K}$ along with $\mathrm{N}$ is very important. Most of Pakistani soils are deficient in available $\mathrm{N}$ and $\mathrm{K}$ and it must be supplemented through fertilizers for the better growth and productivity.

Keeping in view the importance of $\mathrm{N}$ and $\mathrm{K}$ fertilizer application for improved wheat yield and quality, this experiment was initiated to study the response of qualitative and quantitative parameters of wheat to different $\mathrm{N}$ and $\mathrm{K}$ levels in an alkaline calcareous soil.

\section{Materials and methods}

An experiment was conducted in two factors factorial RCB design with three replications to evaluate the impact of three different nitrogen $\left(90,120,150 \mathrm{~kg} \mathrm{~N} \mathrm{ha}^{-1}\right)$ and five potassium $\left(0,30,60,90,120 \mathrm{~kg} \mathrm{~K}_{2} \mathrm{O} \mathrm{ha}^{-1}\right)$ levels on yield and yield components of wheat at Agronomy Research Farm, the University of Agriculture, Peshawar during winter 2013-14. The field was properly prepared and divided into plots of an area $3 \mathrm{~m} \times 5 \mathrm{~m}$. At the time of sowing whole $\mathrm{K}$ and half of $\mathrm{N}$ as per proposed treatment were applied while half $\mathrm{N}$ was applied at tillering stage. Basal dose of $\mathrm{P}$ at the rate of $90 \mathrm{~kg} \quad \mathrm{P}_{2} \mathrm{O}_{5}$ was also applied to all experimental units. Urea, SSP and SOP were used as fertilizer sources for N, P and $\mathrm{K}$, respectively. Wheat variety (Siren) at the rate of $120 \mathrm{~kg}$ seed $\mathrm{ha}^{-1}$ was planted in 30 $\mathrm{cm}$ apart rows. Normal cultural practices were followed throughout the growing season. Data were recorded on days to anthesis, plant height, grains spike ${ }^{-1}, 1000$ grain weight, biological and grain yield. For composite soil sample, $\mathrm{pH}$ and EC were determined in 1:5 soils: water suspension by the method of [7, 8], respectively. Hydrometer method was used to find soil texture as per procedure described by [9]. [10] method was used to find soil organic matter content. Soil lime content was found by acid neutralization method of US salinity staff (1954). Kjeldahl method of [11] was used to find soil total N. AB-DTPA extractable $\mathrm{P}$ in soil samples was determined by [12].

A composite soil samples at the depth of 0$30 \mathrm{~cm}$ was taken before treatment application into the plots and analyzed. The soil of experimental site was silt loam in texture, alkaline in reaction, highly calcareous and non-saline, poor in organic matter, inadequate in total $\mathrm{N}$ and $\mathrm{AB}-\mathrm{DTPA}$ extractable $\mathrm{P}$ contents (Table 1.)

For the statistical analysis of collected data procedure of [13] was used while using Statistix 8.1 package and for any significant difference among the treatments least significant difference (LSD) test was used. 
Table 1. Physico chemical characteristics of experimental site

\begin{tabular}{|l|c|c|}
\hline Property & Concentration & Units \\
\hline Textural class & Silt loam & - \\
\hline $\mathrm{EC}_{\mathrm{e}}$ & 2.75 & $\mathrm{~d} \mathrm{Sm}^{-1}$ \\
\hline $\mathrm{pH}$ & 7.58 & - \\
\hline Organic matter & 0.74 & $\%$ \\
\hline Lime & 18.6 & $\%$ \\
\hline P $(\mathrm{AB}-\mathrm{DTPA}$ extractable $)$ & 2.24 & $\mathrm{mg} \mathrm{kg}^{-1}$ \\
\hline Total N content & 0.09 & $\%$ \\
\hline
\end{tabular}

\section{Results and discussion}

Days to Anthesis

Days to anthesis increased gradually with increasing levels of nitrogen. Maximum numbers of 138.33 days were taken to anthesis with the application of $\mathrm{N}$ at $150 \mathrm{~kg}$ $\mathrm{ha}^{-1}$. Nitrogen applied at of 90 or $120 \mathrm{~kg} \mathrm{ha}^{-1}$ showed 134 days to anthesis indicating that $\mathrm{N}$ fertilizer prolong period to anthesis (Table 2). However, potash fertilizer did not significantly affect days to anthesis in wheat (Table 2). The results of [14] are in line with our findings, who reported that days to anthesis of wheat increased with the increase application of nitrogen.
The interactive effect of $\mathrm{N}$ and $\mathrm{K}$ on days to anthesis in wheat was found significant. The maximum number of 139.4 days were taken to anthesis with the combined application of at $150 \mathrm{~kg} \mathrm{~N} \mathrm{ha}^{-1}$ without $\mathrm{K}$ application. This was however statistically at par with that (139, 138, 138.4 and 137 days taken to anthesis) with combined application of $\mathrm{N}$ at $150 \mathrm{~kg}$ along with $\mathrm{K}$ at $30,60,90$ or $120 \mathrm{~kg}$ $\mathrm{ha}^{-1}$, respectively. The minimum number of 131 days were taken to anthesis with the combine application of $90 \mathrm{~kg} \mathrm{~N}$ and $60 \mathrm{~kg} \mathrm{~K}$ ha $^{-1}$. Similarly [15] also reported significant differences among different $\mathrm{N}$ and $\mathrm{K}$ rates for days to anthesis.

Table 2. Days to Anthesis as affected by combined application of $\mathbf{N}$ and $\mathrm{K}$

\begin{tabular}{|c|c|c|c|c|}
\hline \multirow{2}{*}{ Potassium (kg ha-1) } & \multicolumn{3}{|c|}{ Nitrogen $\left(\mathbf{k g ~ h a}^{-\mathbf{1}}\right)$} & \multirow{2}{*}{ Mean } \\
\cline { 2 - 4 } & $\mathbf{9 0}$ & $\mathbf{3 2 0}$ & $\mathbf{1 5 0}$ & \multirow{2}{*}{ Days to anthesis } \\
\cline { 2 - 4 } & \multicolumn{3}{|c|}{$139.4 \mathrm{a}$} & 135.6 \\
\hline 0 & $133.0 \mathrm{efg}$ & $134.7 \mathrm{cdef}$ & $139.0 \mathrm{a}$ & 134.0 \\
\hline 30 & $132.0 \mathrm{fg}$ & $131.0 \mathrm{~g}$ & $138.0 \mathrm{ab}$ & 134.4 \\
\hline 60 & $131.4 \mathrm{fg}$ & $133.7 \mathrm{defg}$ & $138.4 \mathrm{ab}$ & 135.2 \\
\hline 90 & $135.0 \mathrm{cde}$ & $132.0 \mathrm{fg}$ & $137.0 \mathrm{abc}$ & 135.2 \\
\hline 120 & $132.4 \mathrm{efg}$ & $136.0 \mathrm{bcd}$ & $138.4 \mathrm{a}$ & \\
\hline Mean & $132.8 \mathrm{~b}$ & $133.5 \mathrm{~b}$ & \\
\hline
\end{tabular}

$\operatorname{LSD}(5 \%)$ for $\mathrm{N}=1.26, \mathrm{~K}=\mathrm{NS}, \mathrm{N} * \mathrm{~K}=1.3$

\section{Plant height}

Results regarding plant height are presented in Table 3. Both nitrogen and potassium showed significant effects on plant height of wheat. The plant height increased gradually with increasing levels of nitrogen and potassium. On average, among the $\mathrm{N}$ treatments, maximum plant height of $88 \mathrm{~cm}$ was obtained with the application of $\mathrm{N}$ at $150 \mathrm{~kg} \mathrm{ha}^{-1}$ which was statistically similar to $86.4 \mathrm{~cm}$ produced with $120 \mathrm{~kg} \mathrm{~N} \mathrm{ha}^{-1}$, but significantly higher than $84.6 \mathrm{~cm}$ observed at $90 \mathrm{~kg} \mathrm{~N} \mathrm{ha}^{-1}$. With respect to the response of plant height to potassium, maximum plant height of $89.2 \mathrm{~cm}$ was obtained with $120 \mathrm{~kg}$ $\mathrm{k}_{2} \mathrm{O}$ ha $^{-1}$ which was statically at par with 
that obtained with 90,60 and $30 \mathrm{~kg} \mathrm{k}_{2} \mathrm{O} \mathrm{ha}^{-1}$ but significantly greater than control . It was evident from these results that application of potassium even at the lowest level of $30 \mathrm{~kg}$ $\mathrm{K}_{2} \mathrm{O}$ ha $^{-1}$ significantly increased plant height of wheat over the control treatment. Similar results have also been reported by [16] where nitrogen and $\mathrm{K}_{2} \mathrm{O}$ application had positive effects on plant height of which crop?

The interactive effect of $\mathrm{N}$ and $\mathrm{K}$ on plant height of wheat was significant. The taller plants $(91.3 \mathrm{~cm})$ were recorded with the combined application of NK at 90: $90 \mathrm{~kg} \mathrm{ha}^{-}$ 1 , it was statistically similar to plant height produced at all NK combination except those which received no potassium. The lowest plant height $(70.8 \mathrm{~cm})$ was obtained at $90 \mathrm{~kg} \mathrm{~N}$ used without $\mathrm{K}$ application. Similar results were also reported by [17] where higher and equal proportion of $\mathrm{N}$ and $\mathrm{K}$ significantly increased plant height, grain yield and biological yield of wheat crop.

Table 3. Plant height affected by combined application of $\mathbf{N}$ and $\mathrm{K}$

\begin{tabular}{|c|c|c|c|c|c|}
\hline \multirow{3}{*}{$\begin{array}{l}\text { Potassium } \\
\left(\mathrm{Kg} \mathrm{ha}^{-1}\right)\end{array}$} & \multicolumn{3}{|c|}{ Nitrogen $\left(\mathrm{Kg} \mathrm{ha}^{-1}\right)$} & \multirow[t]{3}{*}{ Mean } & \multirow{3}{*}{$\begin{array}{c}\text { Increase } \mathbf{B y} \\
\text { potassium }\end{array}$} \\
\hline & 90 & 120 & 150 & & \\
\hline & \multicolumn{3}{|c|}{ Plant height $(\mathrm{cm})$} & & \\
\hline 0 & $70.8 \mathrm{~d}$ & $80.2 \mathrm{c}$ & $84.3 \mathrm{bc}$ & $78.4 \mathrm{~b}$ & $0 \%$ \\
\hline 30 & $86.3 \mathrm{ab}$ & $86.6 \mathrm{ab}$ & $89.9 \mathrm{a}$ & $87.6 \mathrm{a}$ & $8 \%$ \\
\hline 60 & $87.0 \mathrm{ab}$ & $86.9 \mathrm{ab}$ & $86.6 \mathrm{ab}$ & $86.9 \mathrm{a}$ & $6 \%$ \\
\hline 90 & $91.3 \mathrm{a}$ & $87.2 \mathrm{ab}$ & $89.8 \mathrm{a}$ & $89.4 \mathrm{a}$ & $8 \%$ \\
\hline 120 & $87.7 \mathrm{ab}$ & $91.0 \mathrm{a}$ & $89.0 \mathrm{ab}$ & $89.2 \mathrm{a}$ & $9 \%$ \\
\hline Mean & $84.6 \mathrm{~b}$ & $85.8 \mathrm{~b}$ & $88.5 \mathrm{a}$ & & \\
\hline
\end{tabular}

$\mathrm{LSD}_{(5 \%)}$ for $\mathrm{N}=2.29, \mathrm{~K}=2.95$ and $\mathrm{N}^{*} \mathrm{~K}=5.12$

\section{Grains spike ${ }^{-1}$}

Grain per spike increased significantly with the increase in nitrogen and potassium level (Table 4). On average, the maximum number of grains (45.4) were produce at 120 $\mathrm{kg} \mathrm{N} \mathrm{ha}^{-1}$. $\mathrm{N}$ application at the rate of $150 \mathrm{~kg}$ $\mathrm{ha}^{-1}$ produced 44.8 grains per spikethat was significantly greater than $90 \mathrm{~kg} \mathrm{~N} \mathrm{ha-1}$. Simmilarly, on average the highest grain per spike (46.4) was observed at $120 \mathrm{~kg}$ $\mathrm{k}_{2} \mathrm{O} \mathrm{ha}^{-1}$ and this was significantly greater than $\mathrm{K}_{2} \mathrm{O}$ applied at the rate of 30 and 60 $\mathrm{kg} \mathrm{ha}^{-1}$, whereas lower number of grain per spike of 46.1 was recorded for control. It was evident that application of potassium even at the lowest level of $30 \mathrm{~kg} \mathrm{ha}^{-1}$ significantly increased number of grain per spike of wheat over the control treatment. The same results were also reported by [18] - They reported that number of grains per spike increased with the increase in NK levels

The interactive effect of $\mathrm{N}$ and $\mathrm{K}$ on number of grain per spike of wheat was significant. The higher number of grain per spike (50) was obtained with the combined application of $150 \mathrm{~kg} \mathrm{~N}$ and $120 \mathrm{~kg} \mathrm{~K}_{2} \mathrm{O} \mathrm{ha}{ }^{-1}$ while the lowest number of grain per spike (39.3) was obtained with the application of $\mathrm{N}$ at the rate of $90 \mathrm{~kg} \mathrm{~N} \mathrm{ha}{ }^{-1}$ alone. Similarly [19] also reported that grains per spike increase with the increase in application of NK levels. 
Table 4. Grains spike ${ }^{-1}$ as affected by combined application of $\mathbf{N}$ and $\mathrm{K}$

\begin{tabular}{|c|c|c|c|c|c|}
\hline \multirow{3}{*}{$\begin{array}{l}\text { Potassium } \\
\left(\mathrm{Kg} \mathrm{ha}^{-1}\right)\end{array}$} & \multicolumn{3}{|c|}{ Nitrogen $\left(\mathrm{Kg} \mathrm{ha}^{-1}\right)$} & \multirow[t]{3}{*}{ Mean } & \multirow{3}{*}{$\begin{array}{c}\text { \% Increase } \\
\text { By potassium }\end{array}$} \\
\hline & 90 & 120 & 150 & & \\
\hline & \multicolumn{3}{|c|}{ Grains spike $^{-1}$} & & \\
\hline 0 & $39.3 \mathrm{~g}$ & $42.3 \mathrm{f}$ & $43.3 \mathrm{ef}$ & $41.6 \mathrm{~d}$ & 0 \\
\hline 30 & $43.6 \mathrm{def}$ & $42.6 \mathrm{f}$ & $42.6 \mathrm{f}$ & $43.0 \mathrm{c}$ & 4 \\
\hline 60 & 43.6 def & $45.6 \mathrm{bcd}$ & 45.0 cde & $44.7 \mathrm{~b}$ & 8 \\
\hline 90 & $42.6 \mathrm{f}$ & $50.0 \mathrm{a}$ & $46.0 \mathrm{bc}$ & $46.2 \mathrm{a}$ & 11 \\
\hline 120 & 45.4 bcde & $46.4 \mathrm{bc}$ & $47.4 \mathrm{~b}$ & $46.4 \mathrm{a}$ & 12 \\
\hline Mean & $42.9 \mathrm{~b}$ & $45.4 \mathrm{a}$ & $44.8 \mathrm{a}$ & & \\
\hline
\end{tabular}

$\operatorname{LSD}(5 \%)$ for $\mathrm{N}=0.97, \mathrm{~K}=1.26 \& \mathrm{~N} * \mathrm{~K}=2.18$

\section{0- Grain weight}

Data on 1000 grain weight as affected by different levels of $\mathrm{N}$ and $\mathrm{K}$ fertilizer are shown in Table 5. 1000 grain weight increase significantly with the increasing trend in nitrogen and potassium. On the average maximum 1000 grain weight (37.7 g) was obtained at $150 \mathrm{~kg} \mathrm{~N} \mathrm{ha}^{-1}$. The 1000 grain weight of $36.7 \mathrm{~g}$ were produced at 90 $\mathrm{kg} \mathrm{N} \mathrm{ha}{ }^{-1}$ that was significantly higher than $90 \mathrm{~kg} \mathrm{~N} \mathrm{ha}{ }^{-1}$ and statistically similar to that of $\mathrm{N}$ applied at $150 \mathrm{~kg} \mathrm{ha}^{-1}$. These findings are in line with those of [17] who reported that higher $\mathrm{N}$ application had positive effect on 1000 grain weight. Furthermore, these findings suggested that different $\mathrm{N}$ and $\mathrm{K}$ levels influenced to 1000 grain weight. With respect to the response of 1000 grain weight to potassium on average, the maximum 1000 grain weight of $39.9 \mathrm{~g}$ were noted for 90 $\mathrm{kg} \mathrm{K}_{2} \mathrm{O} \mathrm{ha}^{-1}$ and this was statistically different from the rest of $\mathrm{K}_{2} \mathrm{O}$ levels, however 1000 grain weight produced at 120 and $60 \mathrm{~kg} \quad \mathrm{~K}_{2} \mathrm{O}$ ha-1 were statistically

Table 5. 1000 grains weight as affected by combined application of $N$ and $K$

\begin{tabular}{|l|c|c|c|c|c|}
\hline \multirow{3}{*}{ Potassium } & \multicolumn{3}{|c|}{ Nitrogen $\left(\mathbf{K g ~ h a}^{-\mathbf{1}}\right)$} & \multirow{2}{*}{ Mean } & \multirow{2}{*}{$\begin{array}{c}\text { \% increase by } \\
\text { Potassium }\end{array}$} \\
\cline { 2 - 4 } & $\mathbf{9 0}$ & $\mathbf{1 2 0}$ & $\mathbf{1 5 0}$ & & \\
\cline { 2 - 4 } & \multicolumn{2}{|c|}{$\mathbf{1 0 0 0}$ grain weight $\mathbf{( g )}$} & & 0 \\
\hline 0 & $32.7 \mathrm{f}$ & $34.1 \mathrm{ef}$ & $35.0 \mathrm{de}$ & $33.9 \mathrm{~d}$ & 3 \\
\hline 30 & $33.8 \mathrm{ef}$ & $35.2 \mathrm{def}$ & $35.8 \mathrm{de}$ & $34.9 \mathrm{~cd}$ & 11 \\
\hline 60 & $35.9 \mathrm{de}$ & $37.8 \mathrm{bcd}$ & $39.0 \mathrm{bc}$ & $37.5 \mathrm{~b}$ & 18 \\
\hline 90 & $37.2 \mathrm{~cd}$ & $42.4 \mathrm{a}$ & $40.3 \mathrm{ab}$ & $39.9 \mathrm{a}$ & 10 \\
\hline 120 & $36.6 \mathrm{~cd}$ & $32.1 \mathrm{bc}$ & $33.5 \mathrm{ef}$ & $36.6 \mathrm{bc}$ & \\
\hline Mean & $35.4 \mathrm{~b}$ & $36.7 \mathrm{a}$ & $37.7 \mathrm{a}$ & & \\
\hline
\end{tabular}

$\operatorname{LSD}_{(5 \%)}$ for $\mathrm{N}=1.3, \mathrm{~K}=1.7 \& \mathrm{~N} * \mathrm{~K}=2.96$ 


\section{Biological yield}

The result showed that biological yield of wheat improved with increasing levels of $\mathrm{N}$ fertilizer Table 6. This was somehow surprising as our soils are mostly deficient in $\mathrm{N}$ and positive response is obtained almost everywhere in Pakistan. [20] Who reported dry matter production increased with increase in level of nitrogen. On average, the maximum biological yield of $6398 \mathrm{~kg}$ ha ${ }^{1}$ was obtained with the application at $150 \mathrm{~kg}$ $\mathrm{N} \mathrm{ha}^{-1}$ and the lowest yield of $5893 \mathrm{~kg}$ ha-1 was obtained with $\mathrm{N}$ at $90 \mathrm{~kg} \mathrm{~N} \mathrm{ha}^{-1}$ However the differencesin biological yield for 120 and $150 \mathrm{~kg} \mathrm{~N}^{-1}$ were nonsignificant. The biological yield however responded positively to the $\mathrm{K}$ levels. The biological yield of wheat increased gradually with the increase levels of $\mathrm{K}$. On average, the maximum biological yield of $7067 \mathrm{~kg}$ ha-1 was obtained with the application of potassium at $120 \mathrm{~kg} \mathrm{~K}_{2} \mathrm{O} \mathrm{ha}^{-1}$ and this was statistically at par with that obtained with $90 \mathrm{~kg} \quad \mathrm{~K}_{2} \mathrm{O}$ ha $^{-1}$ but was significantly greater than those obtained with lower $\mathrm{K}$ levels (60 and $30 \mathrm{~kg} \mathrm{~K}_{2} \mathrm{O}$ ha ${ }^{1}$ ). It was evident that application of potassium even at the lowest level of $30 \mathrm{~kg}$ $\mathrm{K}_{2} \mathrm{O}$ ha $^{-1}$ significantly increased the biological yield of wheat over the control treatment. The previous finding of [19] are in close proximity with our findings who reported that biological yield increased significantly with the increase in potassium levels. However, differences in biological yield obtained with 30 or $60 \mathrm{~kg} \mathrm{~K}_{2} \mathrm{O} \mathrm{ha}^{-1}$ were statistically non-significant.

The interactive effect of $\mathrm{N}$ and $\mathrm{K}$ on biological yield of wheat was also significant. The greatest biological yield of $7678 \mathrm{~kg}$ ha-1 was obtained with the combined application of $\mathrm{N}$ at $120 \mathrm{~kg}$ and $\mathrm{K}$ at $120 \mathrm{~kg} \mathrm{ha}^{-1}$. This was however, statistically at par with that (6600 kg ha-1) obtained with combined application of $\mathrm{N}$ at $120 \mathrm{~kg}$ and $\mathrm{K}$ at $90 \mathrm{~kg} \mathrm{ha}^{-1}$. The lowest biological yield was obtained at $90 \mathrm{~N} \mathrm{~kg}$ alone but this was statistically at par with those obtained with $\mathrm{N}$ at $120 \mathrm{~kg}$ or $150 \mathrm{~kg}$ with no $\mathrm{K}$ or $\mathrm{N}$ at $90 \mathrm{~kg}$ and $\mathrm{K}$ at $30 \mathrm{~kg} \mathrm{ha}^{-1}$ or $\mathrm{N}$ at $120 \mathrm{~kg}$ and $\mathrm{K}$ at $30 \mathrm{~kg} \mathrm{ha}^{-1}$. Similarly [21-22] observed increase in dry matter yield of wheat due to combine application of $\mathrm{N}$ and $\mathrm{K}$.

Table 6. Biological yield as affected by combined application of $\mathbf{N}$ and $\mathrm{K}$

\begin{tabular}{|c|c|c|c|c|c|}
\hline \multirow{3}{*}{$\begin{array}{l}\text { Potassium } \\
\left(\mathrm{Kg} \mathrm{ha}^{-1}\right)\end{array}$} & \multicolumn{3}{|c|}{ Nitrogen $\left(\mathrm{Kg} \mathrm{ha}^{-1}\right)$} & \multirow[t]{3}{*}{ Mean } & \multirow{3}{*}{$\begin{array}{c}\% \text { Increase } \\
\text { by potassium }\end{array}$} \\
\hline & 90 & 120 & 150 & & \\
\hline & \multicolumn{3}{|c|}{ Biological yield $\left(\mathrm{Kg} \mathrm{ha}^{-1}\right)$} & & \\
\hline 0 & 5022 ef & $5044 \mathrm{def}$ & $4878 \mathrm{f}$ & $4981.4 \mathrm{~d}$ & 0 \\
\hline 30 & $6467 \mathrm{~b}$ & $5522 \mathrm{cde}$ & $5611 \mathrm{~cd}$ & $5866.6 \mathrm{c}$ & 18 \\
\hline 60 & $6622 b$ & $6633 \mathrm{~b}$ & $6556 \mathrm{~b}$ & $6603.7 \mathrm{~b}$ & 33 \\
\hline 90 & $6922 \mathrm{~b}$ & $7678 \mathrm{a}$ & $6600 \mathrm{~b}$ & $7066.8 \mathrm{a}$ & 42 \\
\hline 120 & $6956 \mathrm{~b}$ & $6789 \mathrm{~b}$ & $5822 \mathrm{c}$ & $6522.4 \mathrm{~b}$ & 31 \\
\hline Mean & $5893.2 \mathrm{~b}$ & $6333.4 \mathrm{a}$ & $6398.0 \mathrm{a}$ & & \\
\hline
\end{tabular}

$\operatorname{LSD}_{(5 \%)}$ for $\mathrm{N}=409.2, \mathrm{~K}=486.5 \& \mathrm{~N} * \mathrm{~K}=626.3$

\section{Grain yield $\left(\mathrm{kg} \mathrm{ha}^{-1}\right)$}

Both nitrogen and potassium significantly increased the grain yield of wheat Table 7 . The yield increased gradually with increasing levels of nitrogen and potassium. On average, the maximum grain yield (2647 $\mathrm{kg} \mathrm{ha}^{-1}$ ) was obtained with the application of $\mathrm{N}$ at the rate of $150 \mathrm{~kg} \mathrm{ha}^{-1}$. The yield (2502 $\mathrm{kg} \mathrm{ha}^{-1}$ ) produced with $120 \mathrm{~kg} \mathrm{~N} \mathrm{ha}^{-1}$ was significantly greater than that produced (2361 $\mathrm{kg} \mathrm{ha}^{-1}$ ) with $90 \mathrm{~kg} \mathrm{~N}^{-1}$ but was significantly lower than that produced with 
$150 \mathrm{~kg} \quad \mathrm{~N} \mathrm{ha}{ }^{-1} . \quad[23,24]$ observed that nitrogen application increase grain yield of wheat when compared to control. Similarly the average maximum grain yield $(2775 \mathrm{~kg}$ $\mathrm{ha}^{-1}$ )was obtained with the application of potassium at $120 \mathrm{~kg} \mathrm{~K}_{2} \mathrm{O} \mathrm{ha}^{-1}$ and this was statistically at par with that obtained with 90 $\mathrm{kg} \quad \mathrm{K}_{2} \mathrm{O}$ ha $^{-1}$ but was significantly greater than those obtained with lower $\mathrm{K}$ levels (60 or $30 \mathrm{~kg} \mathrm{~K}_{2} \mathrm{O} \mathrm{ha} \mathrm{ha}^{-1}$ ). It was evident that application of potassium even at the lowest level of $30 \mathrm{~kg} \mathrm{~K} 2 \mathrm{O} \mathrm{ha}^{-1}$ significantly increased the grain yield of wheat over the control treatment.

However differences in grain yield obtained with 30 or $60 \mathrm{~kg} \mathrm{~K}_{2} \mathrm{O}$ ha $^{-1}$ were statistically non-significant. The same results were also obtained by $[25,26]$ they reported that application of potassium even at lowest level significantly increase grian yield of wheat.

The interactive effect of $\mathrm{N}$ and $\mathrm{K}$ on grain yield of wheat was also significant. The highest $\mathrm{t}$ grain yield of $3035 \mathrm{~kg} \mathrm{ha}^{-1}$ was obtained with the combined application of $150 \mathrm{~kg} \mathrm{~N}$ and $120 \mathrm{~kg} \mathrm{~K}_{2} \mathrm{O} \mathrm{ha}^{-1}$. This was however statistically at par with that (2077 $\mathrm{kg}$ ha-1) obtained with combined application of $\mathrm{N}$ at $120 \mathrm{~kg}$ and $\mathrm{K}$ at $90 \mathrm{~kg}$ ha-1. The lowest grain yield of $2094 \mathrm{~kg} \mathrm{ha}^{-1}$ was obtained with the application of $90 \mathrm{~kg} \mathrm{~N} \mathrm{ha}^{-1}$ with control $\mathrm{K}$ but this was statistically at par with those obtained with $\mathrm{N}$ at $120 \mathrm{~kg}$ or $150 \mathrm{~kg}$ with no $\mathrm{K}$ or $\mathrm{N}$ at $90 \mathrm{~kg}$ and $\mathrm{K}$ at 30 $\mathrm{kg}$ ha- 1 or $\mathrm{N}$ at $120 \mathrm{~kg}$ and $\mathrm{K}$ at $30 \mathrm{~kg}$ ha- 1 . [19] has reported that different levels of $\mathrm{N}$ and $\mathrm{K}$ affected grain yield significantly.

Table 7. Grain yield as affected by combined application of $N$ and $K$

\begin{tabular}{|c|c|c|c|c|c|}
\hline \multirow{3}{*}{$\begin{array}{l}\text { Potassium } \\
\left(\mathrm{Kg} \mathrm{ha}^{-1}\right)\end{array}$} & \multicolumn{3}{|c|}{ Nitrogen $\left(\mathrm{Kg} \mathrm{ha}^{-1}\right)$} & \multirow[t]{3}{*}{ Mean } & \multirow{3}{*}{$\begin{array}{c}\text { \% Increase } \\
\text { by potassium }\end{array}$} \\
\hline & 90 & 120 & 150 & & \\
\hline & \multicolumn{3}{|c|}{ Grain yield (Kg ha' $\left.{ }^{-1}\right)$} & & \\
\hline 0 & $2094 \mathrm{f}$ & $2219 \mathrm{f}$ & $2226 \mathrm{f}$ & $2180 \mathrm{c}$ & 0 \\
\hline 30 & $2235 \mathrm{f}$ & $2285 \mathrm{ef}$ & $2692 \mathrm{c}$ & $2404 \mathrm{~b}$ & 10 \\
\hline 60 & $2554 \mathrm{~cd}$ & $2692 \mathrm{c}$ & $2538 \mathrm{cde}$ & $2476 \mathrm{~b}$ & 14 \\
\hline 90 & $2746 \mathrm{bc}$ & $2977 \mathrm{ab}$ & $2746 \mathrm{bc}$ & $2686 \mathrm{a}$ & 27 \\
\hline 120 & 2746 bc & $2696 \mathrm{c}$ & $3035 \mathrm{a}$ & $2775 \mathrm{a}$ & 33 \\
\hline Mean & $2361 \mathrm{c}$ & $2502 \mathrm{~b}$ & $2647 \mathrm{a}$ & & \\
\hline
\end{tabular}

$\operatorname{LSD}_{(5 \%)}$ for $\mathrm{N}=119.9, \mathrm{~K}=154.8 \& \mathrm{~N} * \mathrm{~K}=268.1$

\section{Conclusions and recommendations}

Wheat yield and yield components significantly improved with the applications of nitrogen and potassium. It is therefore recommended that nitrogen and potassium should be applied at the rate of $150: 90 \mathrm{~kg}$ $\mathrm{ha}^{-1}$ for the optimum yield of wheat crop under prevailing soil and climatic conditions of Peshawar, Paksitan.

\section{Authors' contributions}

Conceived and designed the experiments: $M$ Adnan, Z Shah, H Ullah \& IU Rahman, Performed the experiments: GA khan, $M$ Arshad \& B khan, Contributed reagents/ materials/ analysis tools: IA Mian, Wrote the paper: A Basir, M Ali \& WU khan.

\section{References}

1. Reddy SR (2004). Agronomy of Field Crops. Kalyani Publishers Ludhiana. p.143

2. Heisey P, Norton GW (2007). Fertilizer and other chemicals. In: R. Evenson and P. Pingali (eds). Handbook of Agricultural Economics, Elsevier BV, Amsterdam. 3:2747-2783.

3. Raun WR, Johnson G (1999). Improving nitrogen useefficiency for cereal production. Agron J Physiol Plant. 91(11): 357-363.

4. Ali A, Choudhry MA, Malik MA, Ahmad R \& Saifullah (2000). Effect of various doses of nitrogen on the growth and yield of two wheat cultivar. Pak J Biol Sci, 3(6): 10041005 . 
5. Shen H, Wang G, Cai Y, Jl X, Shen MX, Wang GW, Cai YH \& Ji XY (1998). The effectiveness of supplementary application of Potassium, Zinc and boron fertilizer to wheat in the Jiziahe district of Jiangsu Province. Jiangsu. Agric Sci, 2: 45-47.

6. Khalid N, Amanullah A \& Asad A (2006). Response of wheat to farm yard manure, potassium and zinc under rainfed cropping patters. (On Line) Middle - East Journal of Scientific Res.

7. Mclean EO (1982). Soil $\mathrm{pH}$ and lime requirement. In Page AL, Milelr RH \& Keeney DR (eds). Methods of soil analysis. Part 2. Agron. 9(2):209-223.

8. Rhoades JD (1982). Testing of soils for salinity and sodicity. In: R.L.Westterman Soil testing and plant analysis. 3: 299-336.

9. Gee GW \& Bauder JW (1986). Partical-size analysis. In: Black WC, Editor, Methods of soil analysis, part 1, America society of Agronomy, Madison, Widconson.

10. Nelson DW \& Sommer LE (1982). Total carbon, Organic carbon and Organic matter. In Page AL, Miller RH \& Keeney DR (eds.) methods of soil analysis part 2 Agron. 9:574-577.

11. Bremner JM \& Mulvaney CS (1982). Nitrogen total. In: Methods of Soil Anaysis of Part-2 Chemical and Microbiological properties. Madison, Wisconsin, USA. 2:595-626.

12. Soltanpour PN \& Schwab AP (1977). A New Soil test for simultaneous extraction of macro and micro nutrients in alkaline soils comm. Soil Sci Plant Anal. 8:195-207.

13. Steel RGD \& Torrie JH (1980). Principles and procedures of statistics. A biometrical approach. McGraw-Hill, New Yorknoxia

15. Smith JW, Naazie A, Larbi A, Agyemang K \& Tarawali SA (1997). Integrated croplivestock systems in sub-Saharan Africa: an option or an imperative? Outlook on Agriculture 26: 237-246.

16. Sharma \& Rad Das N (2002). Response of draft wheat to NPK and Ca. Indian J Plant Physiol, 25: 364-370.

17. Saifullah A, Ranjha M, Yaseen M \& Akhtar MF (2002). Response of wheat to potassium fertilization under field conditions. Pak J Agric Sci. 39 (4): 269272.

18. Alam MM, Alam AKM, Khandker S, Gani MN, Ahmed SA \& Haque A (2002). Fertilizer management of late jute seed production in different agro-ecological zones of Bangladesh. Pakistan J Biol Sci, 5: 410-412.

19. Gul B, Ansari R, Flowers TJ \& Khan MA (2013). Germination strategies of halophyte seeds under salinity. Environ Exp Bot, 92: 4-18,

20. Azad BS, Bhagat BD, Bali SV, Kachroo D \& Gupta SC (1998). Response of late-sown wheat (Triticum aestivum) to seed rate and fertilizer level. Indian Journal of Agronomy. 43(4): 653-656.

21. Dafan TAA, Kholi HMA, Rifaat MGM \& Allah AEA (1999). Effect of soil and foliar application of potassium on yield and mineral content of wheat grains grown in sandy soils. Egypt J Agric Res, 77: 513522.

22. Rajput AL, Singh DP \& Singh SP (1995). Effect of soil and foliar application of nitrogen and zinc with farmyard manure on late-sown wheat (Triticum aestivum). Indian J Agron, 4(40): 598-600.

23. Rathi KS \& Ram Singh (1973). Note on the rates and methods of nitrogen application to Kalyan Sona under rainfed conditions. Indian Journal of Agricultural Research 7(2): 111-114

24. Hameed E, Wajid SA, Shad AA, Bakht J \& Muhammad T (2003). Effect of different planting dates, seed rates and nitrogen levels on wheat. Asian J Plant Sci. 2(6): 464-474.

25. Campillo R, Jobet C \& Undurraga P (2010). Effects of nitrogen on productivity, grain quality, and optimal nitrogen rates in winter wheat cv. kumpainia in andisols of southern Chile. Chilian Journal of Agricultural Research 70: 122-131.

26. Malghani AL, Malik AU, Sattarb A, Hassaina F, Abbasc G \& Hussaind J (2010). Response of growth and yield of wheat to NPK fertilizer. Sci Int (Lahore) 24(2): 185189. 